A N N A L E S

UNIVER S T ATIS M A R A E C URIE-SKŁODOW K A

LUBLIN - POLONIA

VOL. XXXI, 4

SECTIO J

2018

Katolicki Uniwersytet Lubelski Jana Pawła II. Wydział Nauk Społecznych

KATARZYNA CZUBAK

ORCID: 0000-0001-9971-9362

kasiaczubak@kul.lublin.pl

\title{
Doświadczanie miłości w kontekście teorii więzi przez więźniów i nie-więźniów
}

Prisoners' and Non-prisoners' Experience of Love in the Context of Attachment Theory

\section{STRESZCZENIE}

Literatura przedmiotu wskazuje, że przywiązanie jest kluczowym mechanizmem w rozwoju człowieka. Model przywiązania kształtuje się we wczesnym dzieciństwie i ma wpływ na sposób nawiązywania bliskich relacji w późniejszych fazach życia oraz powstawania różnych zaburzeń psychicznych (Berlin, Cassidy 1999; Bowlby 2007/1969). Celem artykułu jest wskazanie relacji pomiędzy stylami przywiązania a doświadczaniem miłości w grupie więźniów i osób będących na wolności. Przeprowadzono dwa badania: pierwsze to badanie więźniów $(\mathrm{n}=314)$, a drugie - osób z populacji generalnej $(n=259)$. Do badania stylu przywiązania zastosowano Kwestionariusz Stylów Przywiązaniowych M. Plopy (2008), natomiast analizę doświadczania miłości przeprowadzono w oparciu o technikę analizy narracji. Obliczono regresję wielokrotną, aby pokazać, w jaki sposób wymiary przywiązania najlepiej określają sposoby doświadczania miłości. Okazało się, że głównym stylem przywiązania wyjaśniającym doświadczanie miłości jest styl bezpieczny.

Słowa kluczowe: style przywiązania; doświadczanie miłości; więźniowie osadzeni w zakładach karnych

\section{WPROWADZENIE}

Koncepcja J. Bowlby'ego koncentruje się na adaptacyjnej funkcji więzi oraz roli wczesnych doświadczeń w kształtowaniu się tzw. zasobów jednostki (Goldberg 2000). Znaczenie wczesnych relacji dziecka $\mathrm{z}$ opiekunem dla funkcjonowania dorosłej jednostki to jedno z szerzej badanych zagadnień w psychologii. 
Model przywiązania ma wpływ na kształtowanie sfery afektywnej, motywacyjnej oraz spostrzegania siebie (Ainsworth, Blehar, Waters, Wall 1978; Pervin 2002; Bowlby 2007/1969). Styl przywiązania kształtuje się we wczesnym dzieciństwie i wyjaśnia nie tylko ludzką tendencję do tworzenia więzi emocjonalnych z innymi ludźmi, ale także pomaga $\mathrm{w}$ zrozumieniu mechanizmu powstawania różnych zaburzeń psychicznych (Bowlby 2005/1988).

Ludzie cechujący się różnymi stylami przywiązania wykazują szereg interesujących różnic pod względem sposobu przeżywania miłości, stanowiących odzwierciedlenie strategii stosowanej przez rodziców w dzieciństwie (Shaver, Hazan, Bradshaw 1988; Hazan, Shaver 1994; Fonagy 1998; Hesse 1999; Carver, Scheier 2000; Feeney, Noller, Roberts 2000; Waters, Merrick, Treboux, Crowell, Albersheim 2000; Plopa 2005; Ragnoni, Galati, Costa, Crini 2008). Stąd wniosek, iż styl przywiązania może kształtować jakość związków partnerskich oraz wpływać na poziom ufności, jakim obdarzane są osoby w tych związkach. C. Hazan i P. Shaver (1994) określili miłość romantyczną jako integrację przywiązania, opieki, rodzicielstwa i seksualności. Z przedstawionych założeń i badań wynika również, iż teoria przywiązania pozwoliła wyjaśnić zarówno prawidłowe, jak i nieprawidłowe formy miłości (Feeney i in. 2000; Zeifman, Hazan 2000).

M.D.S. Ainsworth i in. (1978) opisali trzy główne wzorce przywiązania: ufny, ambiwalentny i unikający. Kolejni badacze tworzyli podobne lub nieco zmodyfikowane, choć nadal zbieżne, typologie: 1) M. Main i J. Solomon, kontynuując badania nad dziećmi, dodały wzorzec zdezorganizowany; 2) C. Hazan i P. Shaver, badając specyfikę romantycznych związków osób dorosłych, wyróżnili trzy style więzi osób dorosłych: ufny, lękowo-ambiwalentny, unikający; 3) K. Bartholomew stworzyła czterokategorialną typologię stylów przywiązania: ufny, zaabsorbowany, odrzucająco-unikający, lękowo-unikający (Bartholomew, Horowitz 1991; Wallin 2011). Ogólnie ujmując, można stwierdzić, że bezpieczny styl przywiązania (zwany też ufnym) kształtuje się w efekcie prawidłowego rozwoju więzi z opiekunem, natomiast niespójny i zaburzony rozwój wczesnych więzi z opiekunem prowadzi do ukształtowania pozostałych typów przywiązania, określanych jako style pozabezpieczne (Finzi, Cohen, Sapir, Weizman 2000).

Style nasycone lękiem (style pozabezpieczne) współwystępują z dysfunkcjonalnymi aspektami w zakresie doświadczania miłości. Unikający styl przywiązania wiąże się z utrzymywaniem dystansu w miłości, niewykazywaniem potrzeby bliskości, a nawet doznawaniem pewnego zakłopotania w przypadku jej występowania, stąd minimalizowanie częstotliwości nawiązywania związków interpersonalnych. Charakterystyczną cechą zachowania osób, u których dominuje taki styl, jest stosunkowo wysoki poziom gniewu, wrogości czy impulsywności, poza tym doświadczają one uczucia zazdrości i są przekonane, że większość ich nie lubi (Feeney, Noller 1990; Bartolomew, Horowitz 1991). Osoby przywiązane „lękowo-ambiwalentnie” doświadczają miłości obfitującej w zazdrość, wątpliwości, 
nieporozumienia, chwiejność emocjonalną, a zwłaszcza ciągły niepokój przed brakiem miłości lub przed porzuceniem przez partnera (Bartholomew, Horowitz 1991; Carver, Scheier 2000; Feeney i in. 2000). Pozabezpieczne style przywiązania sprzyjają zatem doznaniom niepokoju, emocjonalnej labilności oraz nieefektywnemu radzeniu sobie z problemami, które zaburzają adekwatne doświadczanie miłości w związkach partnerskich. Wykazano ponadto, iż osoby przejawiające pozabezpieczne przywiązanie nie odczuwają zadowolenia $\mathrm{z}$ bliskich relacji z partnerem, przejawiają niechęć i obawy przed angażowaniem się w związek oraz wykazują wiele innych negatywnych emocji (Hazan, Shaver 1987; Feeney, Noller 1990; Carver, Scheier 2000).

\section{HIPOTEZY}

Celem pracy było określenie, jakiego rodzaju relacje występują pomiędzy stylem przywiązania a doświadczaniem miłości partnerskiej. Na podstawie licznych badań wykazano, iż styl przywiązania u dorosłych w związkach romantycznych jest powiązany ze stylem przywiązania z dzieciństwa (Shaver i in. 1988; Fonagy 1998; Hesse 1999; Waters i in. 2000; Ragnoni i in. 2008). Dlatego przypuszczano, iż w narracjach osób z pozabezpiecznymi stylami więzi pojawi się więcej elementów negatywnych, wrogości do partnera, nieadekwatnych w stosunku do istoty miłości zachowań typu „od” czy „przeciw” bądź ambiwalencja emocjonalna. Z kolei osoby reprezentujące bezpieczny styl przywiązania poszukują w swoich związkach interpersonalnej bliskości, są zdolne do tworzenia długotrwałych i satysfakcjonujących związków, nie są skłonne do gniewu czy zachowań agresywnych, stwarzają atmosferę ciepła i bezpieczeństwa. Ponadto tworzą związek stabilny, nasycony pozytywnymi emocjami, dlatego charakteryzuje je radość z pozostawania blisko z partnerem i przekonanie, iż jest on osobą pozytywną (Mikulincer 1998; Feeney i in. 2000). Stąd założenie, iż w narracjach o miłości osób z bezpiecznym wzorcem więzi pojawi się więcej elementów pozytywnych, takich jak pozytywna ocena aktora i partnera, pozytywne emocje, pozytywne zakończenie historii miłości oraz zachowania typu „ku”.

Przeprowadzono dwa badania, w których przyjęto, że istnieje podobny mechanizm określający związek między przywiązaniem a doświadczaniem miłości partnerskiej w grupie więźniów i nie-więźniów. Wybrano grupę więźniów, spodziewając się w niej większego udziału pozabezpiecznych form przywiązania, gdyż - jak pokazują badania - zachowania agresywne są często reakcją na brak poczucia bezpieczeństwa (Guttmann-Steinmetz, Crowell 2006). P. Crittenden (1994), analizując rozwój poszczególnych wzorców przywiązania, postawił hipotezę dotyczącą możliwości powstawania ścieżek psychopatologii. Stwierdził, że dzieci z ambiwalentnym wzorcem przywiązania przejawiają różnorodne zaburzenia zachowania, zarówno agresję, jak i zaburzenia prowokacyjne, których 
celem jest zwrócenie na siebie uwagi. Na podstawie przytoczonych badań można założyć, iż wzór przywiązania niedający poczucia bezpieczeństwa może stać się czynnikiem ryzyka powstawania zaburzeń (Sroufe, Carlson, Levy, Egeland 1999). W grupie osób uzależnionych od alkoholu i innych substancji psychoaktywnych także dominują osoby z pozabezpiecznymi stylami przywiązania (Thorberg, Lyvers 2006; de Rick, Vanheule 2007; Juen, Arnold, Meissner, Nolte, Buchheim 2013; Wedekind i in. 2013). Procentowy rozkład występowania stylu bezpiecznego u osób uzależnionych waha się od 5,4 do 40\%, natomiast stylów pozabezpiecznych - od 66 do 94,6\% (de Rick, Vanheule 2007; Harnic i in. 2010; Juen i in. 2013; Wedekind i in. 2013).

Przedmiotem badania uczyniono grupę więźniów, ponieważ wiele wskazuje na to, że zaburzenia przywiązania są istotną zmienną pośredniczącą w przypadku występowania przestępczości. Więźniów charakteryzują ogromne trudności w życiu osobistym i w nawiązywaniu relacji interpersonalnych; mogą się one wiązać z rolą, jaką przywiązanie odgrywa w procesach regulacji emocji czy też w procesach mentalizacyjnych (Sroufe i in. 1999). Doświadczanie miłości przez osoby osadzone jest ważne $\mathrm{z}$ uwagi na to, że miłość jest fundamentalnym uczuciem w relacjach interpersonalnych. Wyniki są bardzo istotne z punktu widzenia diagnozy problemów emocjonalnych i społecznych oraz profilaktyki społecznej.

\section{BADANIE 1}

\section{Metoda}

Osoby badane. Grupę badanych stanowiło 314 więźniów przebywających w zakładach karnych. Średnia wieku to 33,05 roku $(\mathrm{SD}=9,55)$, najmłodszy badany miał 19 lat, a najstarszy - 65 lat. Osoby z tej grupy zostały skazane za wiele poważnych przestępstw przeciwko zdrowiu, życiu i porządkowi publicznemu (na podstawie analizy dokumentacji).

Przebieg badań. Z każdym uczestnikiem został przeprowadzony wywiad uwzględniający stan zdrowia, edukację, sytuację materialną, stan cywilny, sytuację rodzinną oraz relacje w związku partnerskim. Wszystkich badanych cechował brak zaburzeń neuropsychiatrycznych, przeciętny poziom inteligencji oraz brak przewlekłych zaburzeń somatycznych, wzroku i trudności w mówieniu. Udział w badaniu był dobrowolny.

Do badania zastosowano następujące narzędzia badawcze:

1. Kwestionariusz Stylów Przywiązaniowych Plopy (2008) do diagnozy stylów przywiązania. Kwestionariusz składa się z 24 stwierdzeń, po osiem dla każdej ze skal. Opiera się on na koncepcji i metodzie Adult Attachment Style Hazan i Shaver (1987). Właściwości psychometryczne Kwestionariusza, takie jak trafność i zgodność wewnętrzna, są dobre (Plopa 2008). 
W analizach wykorzystano trzy subskale mierzące style przywiązaniowe: bezpieczny, lękowo-ambiwalentny, unikowy. Poprzez użycie tej metody mierzono natężenie każdego stylu u osób badanych, zmienne miały postać ilościową.

2. Badanie narracji o miłości. Każda osoba napisała jeden tekst po usłyszeniu następującej instrukcji: „Spróbuj się zastanowić nad tym, czym jest dla Ciebie miłość. Przypomnij sobie wydarzenie w Twoim życiu, które było bądź jest związane z miłością. Napisz o tym historię".

Analizy narracji dokonano metodą sędziów kompetentnych. Technika analizy narracji była stosowana wielokrotnie w odniesieniu do historii miłości i innych emocji (Gawda 2008, 2011). Charakteryzuje się ona właściwą rzetelnością: alfa Cronbacha $=0,923$, współczynnik podziału połówkowego Guttmana =0,623. Zgodność pomiędzy ocenami sędziów kompetentnych była wysoka - W-Kendalla wyniosło w zależności od kategorii od 0,88 do 0,99 .

Na podstawie wcześniejszych badań opracowano listę wskaźników narracji emocjonalnych pod kątem określonych aspektów doświadczania miłości:

- stosowanie przez aktora (osoba pisząca historię jest nazywana aktorem) określeń z kategorii wrogość, np. zabiję tę szmatę,

- stosowanie inwektyw przez aktora, które są przejawem dewaluacji, np. glupia alkoholiczka; była zwykta tirówka,

- aktor: opis pozytywny (liczba określeń pozytywnych wobec aktora, czyli osoby będącej autorem historii), np. jestem bardzo szlachetnym czlowiekiem,

- aktor: opis negatywny (liczba określeń negatywnych wobec aktora, czyli osoby będącej autorem historii), np. jestem degeneratem, nic nie moge jej $d a c$,

- aktor (liczba emocji negatywnych przeżywanych przez osobę piszącą historię), np. jestem zly,

- aktor (liczba emocji pozytywnych przeżywanych przez osobę piszącą historię), np. jestem bardzo zadowolony i szczęśliwy,

- partner (osoba, która jest opisywana w historii jako partner/ka w historii o miłości): opis negatywny (liczba określeń negatywnych), np. głupia oszustka,

- partner: opis pozytywny (liczba określeń pozytywnych), np. ona jest szczęśliwa,

- partner: liczba emocji negatywnych, np. obawiała się o to, co będzie,

- partner: liczba emocji pozytywnych, np. ona jest szczęśliwa; aktywność w sytuacji miłości,

- aktywność „ku” innym (liczba określeń wskazujących na dążenie do innych, jak zbliżanie się, obejmowanie), np. podszedtem blisko niej, przytulitem ja, 
- aktywność „od” innych (liczba określeń wskazujących na unikanie bądź odsuwanie się od innej osoby), np. izoluję się od niej; uciekta,

- aktywność „przeciw” innym (liczba określeń wskazujących na groźby bądź działania mające na celu wyrządzenie szkody innej osobie), np. zniszcze ja,

- duże znaczenie sytuacji, ocena sytuacji miłości (liczba określeń wskazujących na duże znaczenie miłości), np. miłość jest czymś pięknym ...; na dobre i na złe...; ona jest calym moim światem,

- nikłe znaczenie miłości (liczba określeń wskazujących na małe znaczenie miłości), np. miłość to bzdura i nierealna utopia,

- generalizacje: silne zaangażowanie emocjonalne w sytuację miłości, deklaracje bądź sztywność poglądów na temat miłości. Wskaźniki to charakterystyczne wypowiedzi o kategorycznym lub zgeneralizowanym charakterze, np. myślatem, że nigdy nie znajdę kogoś, kto mnie pokocha...; mylitem się, miłość zawsze zwycięży,

- pozytywne zakończenie historii miłości. Wskaźnik to liczba wypowiedzeń na temat pozytywnej puenty historii, np. nasza miłość trwa na śmierć i życie; moja historia miłosna nadal trwa i nigdy się nie skończy,

- negatywne zakończenie historii miłości. Wskaźnik to liczba wypowiedzeń na temat negatywnej puenty historii, np. ona nigdy nie była miłościa mojego życia, dlatego wszystko się skończyło; miłość się wypalita.

Przykład analizowanej historii o miłości (zapis zgodny z oryginałem):

Pracowałem kilka lat w Niemczech, postanowiłem wrócić do Polski do rodziny. I tak w Polsce już po niedługim czasie myślałem, że poznałem kobietę z którą mogę spędzić życie i mieć poważne plany. Pracowaliśmy razem w tej samej firmie, krótko, ale tam się poznaliśmy. Krótko potem przeprowadziła się do mnie, spędzaliśmy wspaniałe chwile. Po kilku miesiącach okazało się, że jest w ciąży. Bardzo się cieszyłem i ona również, chcieliśmy tego dziecka. Było różnie, ale coraz bardziej zaczęła się negatywnie zachowywać w stosunku do mnie, mojej rodziny, jak i do swojej. Okazało się, że kłamała na każdym kroku, aż któregoś dnia uciekła do siebie z dzieckiem, nie podając konkretnych powodów. Zacząłem walczyć o dziecko, ona natomiast, wykorzystując to, że byłem w więzieniu i jestem na przerwie w karze, napisała do ..., że chce, żebym ja wrócił do więzienia. I w ten sposób wróciłem, choć nigdy nie zrobiłem w swoim życiu żadnej kobiecie krzywdy. Ale bronię się do końca i wszystko wskazuje na to, że moja prawda jest silniejsza w sądzie teraz. Mam tylko żal, że ta suka posunęła się do takiego stopnia, żeby wsadzić mnie z powrotem do więzienia. Dla mnie jest to niewybaczalne, ale z synem zawsze będę starał się mieć kontakt i zrobię wszystko, żeby dowiedział się całej prawdy o swojej matce. I tak skończył się mój związek z osobą, której do końca zaufałem. 
Tab. 1. Przykład arkusza oceny wyżej zamieszczonej historii o miłości

\begin{tabular}{|c|c|c|}
\hline Nazwa kategorii & Liczba & $\begin{array}{c}\text { Nazwa i liczba (jeśli są takie same lub zbliżone } \\
\text { kategorie), przykład z tekstu }\end{array}$ \\
\hline Wrogość & 1 & Dla mnie jest to niewybaczalne \\
\hline Inwektywy & 1 & ta suka \\
\hline Aktor - opis pozytywny & 2 & $\begin{array}{c}1 \text { Dobry: nigdy nie zrobiłem w swoim życiu żadnej } \\
\text { kobiecie krzywdy } \\
1 \text { Prawdomówny: moja prawda jest silniejsza }\end{array}$ \\
\hline Aktor - opis negatywny & 0 & - \\
\hline Aktor-emocje negatywne & 2 & $\begin{array}{l}1 \text { Żal: Mam tylko żal } \\
1 \text { Poczucie urazy: Dla mnie jest to niewybaczalne }\end{array}$ \\
\hline Aktor - emocje pozytywne & 3 & $\begin{array}{c}2 \text { Radość: Bardzo się cieszyłem, spędzaliśmy } \\
\text { wspaniate chwile } \\
1 \text { Zaufanie, bezpieczeństwo; której do końca } \\
\text { zaufatem }\end{array}$ \\
\hline Partner - opis negatywny & 5 & $\begin{array}{l}\text { Niedobra: coraz bardziej zaczęła się negatywnie } \\
\text { zachowywać } \\
\text { Kłamliwa: kłamała na każdym kroku } \\
\text { Kapryśna, niedobra: uciekta do siebie z dzieckiem, } \\
\text { nie podając konkretnych powodów } \\
\text { Wykorzystująca: ona natomiast, wykorzystując to } \\
\text { Zła: całej prawdy o swojej matce }\end{array}$ \\
\hline Partner - opis pozytywny & 0 & - \\
\hline Partner - emocje negatywne & 1 & $\begin{array}{l}\text { Wrogość: ta suka posunęta się do takiego stopnia, } \\
\text { żeby wsadzić mnie z powrotem do więzienia }\end{array}$ \\
\hline Partner-emocje pozytywne & 1 & Radość: Bardzo się cieszyłem i ona również \\
\hline Aktywność „ku” & 2 & $\begin{array}{l}\text { spędzaliśmy wspaniate chwile } \\
\text { będę starat się mieć kontakt }\end{array}$ \\
\hline Aktywność „od” & 1 & Uciekta \\
\hline Aktywność „przeciw” & 0 & - \\
\hline Waga (znaczenie) miłości & 0 & - \\
\hline Małe znaczenie miłości & 0 & - \\
\hline $\begin{array}{l}\text { Generalizacje: silne } \\
\text { zaangażowanie emocjonalne, } \\
\text { deklaracje, uogólnienia, } \\
\text { sztywność poglądów. } \\
\text { Wskaźnik to liczba określeń } \\
\text { kategorycznych, generalizacji }\end{array}$ & 6 & $\begin{array}{c}\text { na każdym kroku } \\
\text { nigdy nie zrobitem } \text { w swoim życiu żadnej kobiecie } \\
\text { krzywdy } \\
\text { wszystko wskazuje } \\
\text { zawsze będę starat się } \\
\text { zrobię wszystko } \\
\text { do końca zaufatem }\end{array}$ \\
\hline Pozytywne zakończenie & 0 & - \\
\hline Negatywne zakończenie & 1 & $\begin{array}{c}\text { Mam tylko żal, że ta suka posunęta się do takiego } \\
\text { stopnia, żeby wsadzić mnie z powrotem do więzienia. } \\
\text { I tak skończyt się mój związek z osoba... }\end{array}$ \\
\hline
\end{tabular}

Źródło: opracowanie własne. 
Z zestawienia w tab. 1 wynika, iż w tej historii o miłości dominują negatywne określenia partnerki jako osoby kłamliwej, niedobrej i wykorzystującej. Autor historii bardzo często w opisie używa określeń kategorycznych i generalizacji. Siebie postrzega jako pozytywnego, doświadcza zarówno pozytywnych, jak i negatywnych emocji związanych z sytuacją miłości, wyraża wrogość, żal, a także stosuje inwektywy odnośnie do swojej partnerki. Autor opowiadania o miłości nie wypowiedział się na temat znaczenia miłości ani nie przypisał partnerce właściwie żadnych cech pozytywnych. Historia miłości kończy się negatywnie. Doświadczenie miłości jest zatem zbiorem wrogości, żalu, urazy, z niewielką domieszką radości. Autor historii uwagę skoncentrował na negatywnej ocenie partnerki i pretensjach do niej.

\section{Wyniki}

W celu ustalenia, w jakim stopniu style przywiązania wyjaśniają poszczególne wskaźniki doświadczania miłości, w obu grupach zastosowano wielozmiennową analizę regresji. Jako zmienne wyjaśniające (niezależne) uznano style przywiązania: lękowo-ambiwalentny, unikający i bezpieczny, natomiast zmiennymi wyjaśnianymi (zależnymi) były wskaźniki doświadczania miłości.

Analiza regresji w grupie więźniów wykazała, iż największe znaczenie wyjaśniające w odniesieniu do elementów doświadczania miłości miała zmienna bezpieczny styl przywiązania. Odpowiadał on za $10 \%$ wariancji wyników w zakresie emocji negatywnych i pozytywnych przeżywanych przez aktora historii miłości. Obniżony styl bezpieczny sprzyjał przejawianiu negatywnych emocji przez aktora (np. jestem zly na siebie, że się do tego przyczyniłem; boję się o to, co będzie), natomiast w przypadku nasilenia bezpiecznego stylu przywiązania wzrastała skłonność do odczuwania przez aktora emocji pozytywnych (np. jestem spokojny; jestem szczęśliwy, że tak się stało; cieszę się, że ona mnie wspiera). Styl bezpieczny wraz ze stylem unikającym były powiązane z tworzeniem pozytywnych i negatywnych zakończeń historii o miłości, kolejno wyjaśniając 11\% i 10\% wariancji wyników. Wyższy bezpieczny styl przywiązania i niższy styl przywiązania unikającego sprzyjały formułowaniu pozytywnych zakończeń historii o miłości (np. nasz związek trwa szczęśliwie, a ja zawsze będę starat się, by była najszczęśliwsza kobieta na ziemi; jesteśmy stworzeni dla siebie... nasza miłość będzie trwała po sam grób; możemy na siebie liczyć $i$ nic nie jest w stanie zburzyć naszej miłości). Z kolei obniżony styl bezpieczny i podwyższony styl unikający odpowiadały za formułowanie negatywnych zakończeń historii o miłości (np. rozstaliśmy się, od tej pory postanowitem, że już się nigdy nie zakocham, bo miłości nie ma, nie istnieje; rozstałem się z ta dziwka). Model regresyjny, w którym uwzględniono wskaźniki trzech stylów przywiązania, wyjaśnił 11\% zmienności w zakresie odczuwania przez partnera emocji pozytywnych oraz oceny miłości jako ważnego wydarzenia, przy czym istotnymi predyktorami były styl bezpieczny i styl unikający. Ponadto ten sam model wyjaśnił 
Tab. 2. Wyniki wielozmiennowej analizy regresji (zmienne zależne - wskaźniki doświadczania miłości; zmienne niezależne - style przywiązania) - więźniowie $(\mathrm{n}=314)$

\begin{tabular}{|c|c|c|c|c|c|c|}
\hline \multirow{2}{*}{ Doświadczanie miłości } & PL-A & $\mathrm{PU}$ & $\mathrm{PB}$ & \multirow{2}{*}{$\mathrm{R}$} & \multirow{2}{*}{$\mathrm{R}^{2}$} & \multirow{2}{*}{$\mathrm{F}_{(3,310)}$} \\
\hline & $\beta$ & $\beta$ & $\mathrm{B}$ & & & \\
\hline Wrogość aktora & 0,05 & 0,05 & $-0,21 * * *$ & 0,26 & 0,07 & $7,74 * * *$ \\
\hline Inwektywy aktora & 0,06 & 0,04 & $-0,16^{* *}$ & 0,21 & 0,04 & $4,79 * *$ \\
\hline Aktor - opis negatywny & $0,14^{*}$ & $-0,10$ & $-0,04$ & 0,11 & 0,01 & 1,40 \\
\hline Aktor - opis pozytywny & 0,06 & $-0,02$ & 0,06 & 0,08 & 0,01 & 0,83 \\
\hline Aktor - emocje negatywne & 0,01 & 0,13 & $-0,24 * * *$ & 0,32 & 0,10 & $12,44 * * *$ \\
\hline Aktor-emocje pozytywne & $-0,01$ & $-0,13$ & $0,24 * * *$ & 0,32 & 0,10 & $12,30 * * *$ \\
\hline Partner - opis negatywny & 0,01 & $0,18 * *$ & $-0,12 *$ & 0,26 & 0,06 & $7,68 * * *$ \\
\hline Partner - opis pozytywny & 0,02 & $-0,17^{*}$ & 0,09 & 0,22 & 0,05 & $5,43 * * *$ \\
\hline Partner-emocje negatywne & 0,08 & $-0,02$ & $-0,04$ & 0,08 & 0,01 & 0,81 \\
\hline Partner-emocje pozytywne & 0,01 & $-0,21 * *$ & $0,18 * *$ & 0,33 & 0,11 & $12,80 * * *$ \\
\hline Aktywność „ku” & 0,07 & $-0,22 * *$ & 0,09 & 0,24 & 0,05 & $6,39 * * *$ \\
\hline Aktywność „od” & $0,13^{*}$ & 0,08 & $-0,17 * *$ & 0,29 & 0,08 & $9,61 * * *$ \\
\hline Ważna sytuacja & 0,09 & $-0,19 * *$ & $0,20 * * *$ & 0,31 & 0,09 & $11,30 * * *$ \\
\hline Generalizacje & 0,12 & $-0,18^{*}$ & $0,14^{*}$ & 0,24 & 0,06 & $6,67 * * *$ \\
\hline Pozytywne zakończenie & 0,04 & $-0,16^{*}$ & $0,25 * * *$ & 0,34 & 0,11 & $13,49 * * *$ \\
\hline Negatywne zakończenie & $-0,02$ & $0,17^{*}$ & $-0,21 * * *$ & 0,32 & 0,10 & $11,86^{* * *}$ \\
\hline
\end{tabular}

PL-A - przywiązanie lękowo-ambiwalentne; PU - przywiązanie unikowe; PB - przywiązanie bezpieczne; * istotne na poziomie $\mathrm{p}<0,05 ; * *$ istotne na poziomie $\mathrm{p}<0,01$; ** istotne na poziomie $\mathrm{p}<0,001$

Źródło: opracowanie własne.

6\% zmienności wyników w zakresie stosowania generalizacji. Im wyższe wyniki w zakresie bezpiecznego stylu przywiązania i niższe w zakresie stylu unikającego, tym bardziej wzrastała skłonność do opisywania partnera przez pryzmat emocji pozytywnych (np. ona jest szczęśliwa, bo wie, że jest najważniejsza kobieta w moim $\dot{z} y c i u$ ). Dodatkowo wzrastała skłonność do wskazywania na ważność miłości, jak również formułowania generalizacji (np. miłość jest ważna i poszukiwana przez wszystkich... ja właśnie teraz przeżywam ta prawdziwa mitość, która jest tylko raz w życiu i która mnie już nigdy nie spotka). Opisy świadczące o tym, że miłość jest sytuacją ważną, to np.: miłość jest czymś pięknym ... na dobre i na złe... ona jest całym moim światem; ona jest moja najważniejsza miłościa, jest oddana, by walczyć z przeciwnościami losu o mnie i o dzieci. Aktywność „od” innych została wyjaśniona przez przywiązanie bezpieczne i lękowo-ambiwalentne w zakresie $8 \%$ wariancji wyników. Im wyższe nasilenie przywiązania lękowo-ambiwalentnego i niższe nasilenie przywiązania bezpiecznego, tym większa tendencja do działań „od ludzi" (np. izoluję się od niej; uciekta, zabrała dzieci, nie chce mnie znać). Działa- 
nia „ku innym” zostały natomiast wyjaśnione w zakresie 5\% zmienności wyników przez przywiązanie unikające. Obniżone wyniki w zakresie unikowego stylu przywiązania sprzyjały podejmowaniu aktywności „ku” innym (np. podszedtem blisko niej; przytulitem ja). Z kolei skłonność do stosowania wrogości i inwektyw przez aktora była powiązana $\mathrm{z}$ obniżonymi wynikami w zakresie stylu bezpiecznego kolejno 7\% i 4\% wariancji wyników odpowiada za ten model. Wówczas pojawiały się w historiach wypowiedzi wskazujące na wrogość w rodzaju będę z niq walczyć o moje dziecko oraz następujące inwektywy: głupia alkoholiczka; była zwykta tirówka, dlatego traktowałem ja jak szmatę. Osoby z obniżonym stylem bezpiecznym oraz z podwyższonym stylem unikającym opisywały partnera w sposób negatywny (6\% wariancji wyników), np. ona była zwykła oszustka zachłanna na pieniadze; jest niegodna zaufania i nieodpowiedzialna, nawet nie potrafi dobrze wychować naszego syna. Tendencja do opisywania partnera w sposób pozytywny wiązała się zaś ze stylem unikającym (w zakresie 5\% wariancji wyników): im niższe wyniki w zakresie stylu unikającego, tym większa tendencja do opisywania innych w kategoriach pozytywnych (np. ona umie stuchać, wie, kiedy potrzebuje pomocy; ona jest bardzo dobra i madra).

Żadna ze zmiennych w założonym modelu nie wyjaśniła zmienności wyników w zakresie pozytywnego opisu aktora ani emocji negatywnych partnera.

\section{BADANIE 2}

\section{Metoda}

Osoby badane. Grupę badaną stanowiło 259 osób wyłonionych z populacji generalnej. Byli to studenci różnych kierunków studiów stacjonarnych i niestacjonarnych oraz osoby niebędące studentami, które wyraziły zgodę na udział w badaniu. Średnia wieku dla tej grupy to 23,98 roku $(\mathrm{SD}=9,33)$, najmłodszy badany miał 18 lat, a najstarszy - 62 .

Przebieg badań. Z każdym uczestnikiem został przeprowadzony wywiad w celu określenia tych samych cech, które zostały wskazane w badaniu 1. Udział w badaniu był dobrowolny.

W badaniu osób z populacji generalnej wykorzystano te same techniki, co w badaniu 1: Kwestionariusz Stylów Przywiązaniowych Plopy (2008) oraz badanie narracji (Gawda 2008, 2011).

\section{Wyniki}

Dane zamieszczone w tab. 3 wskazują, że więźniowie istotnie rzadziej niż osoby z populacji generalnej opisywali siebie w kategoriach pozytywnych oraz odczuwali emocje negatywne. Ponadto wykazano, że więźniowie rzadziej niż 
osoby z populacji generalnej opisywali partnera w sposób pozytywny oraz przypisywali mu emocje negatywne i pozytywne. Dodatkowo ważność sytuacji miłości była istotnie większa u więźniów niż w grupie osób z populacji generalnej. Warto tu zaznaczyć, że obie grupy różniły się w zakresie wieku, ponieważ średni wiek więźniów to 33 lata, a osób z populacji generalnej - niespełna 24 lata, a niemal dekada różnicy w młodym wieku wydaje się znacząca.

Tab. 3. Porównania międzygrupowe w zakresie badanych zmiennych pomiędzy więźniami a grupą osób z populacji generalnej (test U Manna-Whitneya dla dwóch grup niezależnych)

\begin{tabular}{|c|c|c|c|}
\hline \multirow{3}{*}{ Zmienne } & Grupa więźniów & $\begin{array}{c}\text { Grupa osób z populacji } \\
\text { generalnej }\end{array}$ & \multirow{2}{*}{$\begin{array}{c}\text { Test } \\
\text { U-Manna-Whitneya }\end{array}$} \\
\hline & $\mathrm{n}=314$ & $\mathrm{n}=259$ & \\
\hline & $\mathrm{M}(\mathrm{SD})$ & $\mathrm{M}(\mathrm{SD})$ & $\mathrm{Z}$ \\
\hline Styl bezpieczny & $40,87(10,03)$ & $41,03(9,26)$ & $-0,05$ \\
\hline Styl lękowo-ambiwalentny & $29,21(10,41)$ & $27,57(10,36)$ & $-1,85$ \\
\hline Styl unikający & $23,97(10,42)$ & $22,24(9,41)$ & $-1,90$ \\
\hline \multicolumn{4}{|c|}{ DOŚWIADCZANIE MIŁOŚCI } \\
\hline Wrogość aktora & $0,23(0,43)$ & $0,17(0,38)$ & $-1,49$ \\
\hline Inwektywy aktora & $0,14(0,44)$ & $0,10(0,32)$ & $-0,70$ \\
\hline Aktor - opis negatywny & $0,14(0,38)$ & $0,12(0,33)$ & $-0,56$ \\
\hline Aktor - opis pozytywny & $0,49(0,60)$ & $0,73(0,51)$ & $-5,64 * * *$ \\
\hline Aktor - emocje negatywne & $1,46(1,33)$ & $1,88(1,43)$ & $-3,64 * * *$ \\
\hline Aktor - emocje pozytywne & $1,09(1,05)$ & $1,08(0,92)$ & $-0,16$ \\
\hline Partner - opis negatywny & $0,44(0,75)$ & $0,46(0,71)$ & $-0,75$ \\
\hline Partner - opis pozytywny & $0,60(0,73)$ & $0,81(0,70)$ & $-3,98 * * *$ \\
\hline Partner-emocje negatywne & $0,31(0,63$ & $0,68(0,01)$ & $-5,59 * * *$ \\
\hline Partner-emocje pozytywne & $0,55(0,72)$ & $0,76(0,83)$ & $-3,15^{* *}$ \\
\hline Aktywność „ku” & $1,10(0,86)$ & $1,21(0,91)$ & $-1,53$ \\
\hline Aktywność „od” & $0,74(0,78)$ & $0,80(0,83)$ & $-0,75$ \\
\hline Aktywność „przeciw” & $0,08(0,30)$ & $0,05(0,22)$ & $-0,96$ \\
\hline Ważna sytuacja & $0,51(0,53)$ & $0,42(0,51)$ & $-2,18^{*}$ \\
\hline Generalizacje & $0,44(0,57)$ & $0,42(0,58)$ & $-0,65$ \\
\hline Pozytywne zakończenie & $1,41(0,49)$ & $1,54(0,50)$ & $-3,04 * *$ \\
\hline Negatywne zakończenie & $1,54(0,48)$ & $1,44(0,49)$ & $-2,35^{*}$ \\
\hline
\end{tabular}

$*$ istotne na poziomie $\mathrm{p}<0,05$; ** istotne na poziomie $\mathrm{p}<0,01$; *** istotne na poziomie $\mathrm{p}<0,001$ Źródło: opracowanie własne. 
Przeprowadzona analiza regresji, obejmująca zmienne wyjaśniające style przywiązaniowe, wyjaśniła istotny procent wariancji wyników w zakresie doświadczania miłości w grupie osób z populacji generalnej.

Tab. 4. Wyniki wielozmiennowej analizy regresji (zmienne zależne - wskaźniki doświadczania miłości; zmienne niezależne - style przywiązania) - grupa osób z populacji generalnej ( $\mathrm{n}=259)$

\begin{tabular}{|c|c|c|c|c|c|c|}
\hline \multirow{2}{*}{ Elementy skryptu miłości } & PL-A & $\mathrm{PU}$ & $\mathrm{PB}$ & \multirow{2}{*}{$\mathrm{R}$} & \multirow{2}{*}{$\mathrm{R}^{2}$} & \multirow{2}{*}{$\mathrm{F}_{(3,255)}$} \\
\hline & $\beta$ & $\beta$ & B & & & \\
\hline Wrogość aktora & 0,05 & 0,09 & $-0,20^{*}$ & 0,30 & 0,09 & $8,41^{* * *}$ \\
\hline Inwektywy aktora & 0,04 & $-0,09$ & $-0,18^{*}$ & 0,14 & 0,02 & 1,79 \\
\hline Aktor - opis negatywny & $-0,05$ & $0,21 *$ & 0,03 & 0,16 & 0,02 & 2,50 \\
\hline Aktor-opis pozytywny & 0,06 & $-0,22 *$ & 0,03 & 0,22 & 0,05 & $4,59 * *$ \\
\hline Aktor-emocje negatywne & 0,08 & $-0,04$ & $-0,29 * * *$ & 0,29 & 0,08 & $8,02 * * *$ \\
\hline Aktor-emocje pozytywne & $-0,05$ & $-0,06$ & $0,28 * * *$ & 0,35 & 0,12 & $12,35 * * *$ \\
\hline Partner - opis negatywny & 0,12 & $-0,10$ & $-0,29 * * *$ & 0,26 & 0,07 & $6,64 * * *$ \\
\hline Partner - opis pozytywny & $-0,05$ & 0,01 & $0,36^{* * *}$ & 0,36 & 0,13 & $13,13 * * *$ \\
\hline Partner-emocje negatywne & $-0,02$ & 0,04 & $-0,02$ & 0,05 & 0,01 & 0,25 \\
\hline Partner-emocje pozytywne & $-0,04$ & $-0,06$ & $0,29 * * *$ & 0,35 & 0,12 & $12,37 * * *$ \\
\hline Aktywność „ku” & 0,01 & $-0,12$ & $0,21 *$ & 0,30 & 0,09 & $8,73 * * *$ \\
\hline Aktywność „od” & $-0,01$ & 0,05 & $-0,07$ & 0,11 & 0,01 & 1,03 \\
\hline Ważna sytuacja & 0,08 & 0,03 & $0,19 *$ & 0,17 & 0,03 & $2,70^{*}$ \\
\hline Generalizacje & 0,05 & $-0,10$ & 0,01 & 0,09 & 0,01 & 0,84 \\
\hline Pozytywne zakończenie & 0,02 & $-0,06$ & $0,33 * * *$ & 0,37 & 0,14 & $13,89 * * *$ \\
\hline Negatywne zakończenie & $-0,02$ & 0,08 & $-0,32 * * *$ & 0,38 & 0,14 & $14,76^{* * *}$ \\
\hline
\end{tabular}

PL-A - przywiązanie lękowo-ambiwalentne; PU - przywiązanie unikające; PB - przywiązanie bezpieczne; * istotne na poziomie $\mathrm{p}<0,05$; ** istotne na poziomie $\mathrm{p}<0,01 ; * * *$ istotne na poziomie $\mathrm{p}<0,001$

Źródło: opracowanie własne.

Przywiązanie bezpieczne okazało się mieć decydujące znaczenie wyjaśniające, gdyż objaśniło $12 \%$ wariancji wyników w zakresie odczuwania emocji pozytywnych zarówno przez aktora, jak i przez partnera historii miłości. Dominacja bezpiecznego stylu przywiązania wiązała się ze wzrostem pozytywnych emocji u aktora (np. jestem szczęśliwy $i$ zadowolony) oraz partnera (np. jest bardzo radosna). Ponadto im wyższy bezpieczny styl przywiązania, tym bardziej wzrastała skłonność do opisywania partnera w sposób pozytywny (ten model odpowiada za 13\% zmienności wyników). Przykładowe opisy partnera w sposób pozytywny: nigdy nie widziałem tak szczerej i oddanej osoby, jak moja dziewczyna, ona jest bardzo madra i rozsądna; jest uczciwa i opiekuńcza. Przywiązanie bezpieczne wyjaśniło także $9 \%$ wariancji wyników w zakresie skłon- 
ności do wrogości u aktora i $8 \%$ wariancji wyników w zakresie odczuwania przez aktora emocji negatywnych. Oznacza to, że im wyższy bezpieczny styl przywiązania, tym rzadziej pojawiała się wrogość w opowiadaniach o miłości (np. mam nadzieję, że ktoś tė̇ ja tak zrani, jak ona mnie; aż mnie trzęsie, jak ja widzę; ona teraz powinna cierpieć za to, co mi zrobita) oraz odczuwania emocji negatywnych przez aktora (np. jestem zły na wszystko i na wszystkich; boję sie o nasza przyszłość; byłem bardzo smutny, gdy dowiedziałem się, że mnie oszu$k a ł a)$. Sposób predykcji zakończenia historii miłości w znaczącym stopniu był uwarunkowany bezpiecznym stylem przywiązania (14\% wariancji wyników). Podwyższone wyniki w zakresie bezpiecznego stylu przywiązania wiązały się z pozytywnym postrzeganiem zakończenia miłości (np. postanowiliśmy trzymać się zawsze razem, nie ustępując trudnościom, które zapewne przygotowato dla nas życie; nasza miłość trwa na śmierć i życie; moja historia miłosna nadal trwa i nigdy się nie skończy). Natomiast obniżone wyniki w zakresie bezpiecznego stylu przywiązania wiązały się z przewidywaniem negatywnego zakończenia historii miłości. Przykłady takich zakończeń są następujące: straciłem kogoś, kogo nigdy nie odzyskam i nikt nie jest w stanie zastapić tej pustki; ona nigdy nie byta miłościa mojego życia, dlatego wszystko się skończyło; miłość się wypalita, ludzie nigdy nie niosa ze soba czegoś trwatego. Przywiązanie bezpieczne wyjaśniło 9\% wariancji wyników w zakresie aktywności „ku” innym. Podwyższony styl bezpieczny wiązał się z większą częstością działań „ku” innym (np. podchodzę do niej; podatem jej rękę), jak również z negatywnym opisem partnera. Ponadto zmienna ta wyjaśniła 7\% wariancji wyników w tym zakresie w taki sposób, że im niższe wyniki w zakresie bezpiecznego stylu przywiązania, tym większa tendencja do opisywania partnera w sposób negatywny (np. jest dobrze manipulujaca oszustka; ona jest ktamliwa; jest bezwstydna).

Przywiązanie unikowe wyjaśniło 5\% wariancji wyników w zakresie pozytywnego opisu aktora w taki sposób, iż obniżenie unikającego stylu przywiązania wiązało się ze wzrostem tendencji do postrzegania siebie w barwach pozytywnych (np. jestem dobry; jestem bardzo szlachetnym czlowiekiem), a uznanie wydarzenia miłości za ważne było wyjaśniane przez styl bezpieczny w zakresie jedynie $3 \%$ wariancji wyników. Przy wyższych wynikach w zakresie bezpiecznego stylu przywiązania miłość jawiła się jako ważne uczucie (np. miłość jest czymś pięknym, dlatego pokochatem ja na zawsze; myślatem, że nigdy nie znajdę kogoś, kto mnie pokocha ... mylitem się, mitość wszystko zwycięży).

Żadna ze zmiennych w założonym modelu nie wyjaśniła zmienności wyników w zakresie emocji negatywnych partnera, aktywności „od” oraz stosowania generalizacji. 


\section{DYSKUSJA}

Doświadczenie miłości to indywidualny sposób postrzegania i odbierania miłości. Ma ono swoją strukturę wewnętrzną, którą tworzą powiązane ze sobą relacje bardziej elementarnych składowych miłości. Zgodnie z założeniami teorii narracyjnych sposobem dotarcia do tego doświadczenia jest narracja, ponieważ ukazuje, w jaki sposób osoby nadają znaczenie miłości, jak ją odbierają i jakie emocje i przeżycia z nią wiążą (Sternberg, Weis 2007). Tak rozumiane doświadczenie miłości było przedmiotem badań w niniejszej pracy. Uzyskane rezultaty ogólnie wskazały, iż kluczową rolę w zakresie doświadczania miłości w obu badanych grupach pełnił bezpieczny styl przywiązania. Sprzyjał on pozytywnemu nacechowaniu takiego doświadczenia w postaci przypisywania emocji pozytywnych aktorowi, a także opisowi partnera w barwach pozytywnych i rejestrowaniu u niego emocji pozytywnych, zwiększonej aktywności typu „ku”, dostrzeganiu wagi miłości oraz przewidywaniu pozytywnej (a nie negatywnej) puenty historii miłości. Styl bezpieczny przywiązania nie sprzyjał negatywnemu nacechowaniu doświadczania miłości (tj. doświadczaniu wrogości w relacjach miłosnych, doświadczaniu negatywnych emocji przez aktora, negatywnemu opisowi partnera). Ponadto pozabezpieczny styl przywiązania był predyktorem dla doświadczania miłości w taki sposób, iż nacechowywał to doświadczenie negatywnie i czynił je nieklarownym. W szczególności dotyczy to stylu unikającego u więźniów, który częściej sprzyjał opisywaniu partnera w sposób negatywny, rzadziej zaś w pozytywny, oraz obniżeniu dostrzegania u niego emocji pozytywnych. Dodatkowo prowadził do: zmniejszenia aktywności typu „ku”, deficytu silnego zaangażowania emocjonalnego w sytuację miłości, niewielkiego znaczenia miłości oraz przewidywania częściej negatywnego zakończenia historii i rzadziej pozytywnego jej finału.

Wyniki badań potwierdzają dane z literatury przedmiotu wskazujące na to, że u osób, u których dominują pozabezpieczne style przywiązania (tj. lękowo-ambiwalentny czy unikowy), dochodzi do zniekształcania odbieranych informacji w kierunku zgodnym z głęboko zakorzenionymi przekonaniami na temat własnej bezwartościowości, zależności i poczucia braku zaufania. Takie osoby wykazują też trudność w osiąganiu określonych zamierzeń i odnoszeniu satysfakcji z ich realizacji (Cassidy 1994). Inny obraz relacji zdaje się wynikać z powiązań pomiędzy bezpiecznym modelem przywiązania i aktualną sytuacją partnerską. Dorośli, których w dzieciństwie łączył z rodzicami związek o charakterze bezpiecznym, tworzą trwałe, dojrzałe i pełne zaufania związki (Thompson, Goodvin 2007). Ustalenia z badań potwierdzają ważność konstruktu Bowlby'ego jako wyznacznika jakości funkcjonowania oraz budowania relacji. Bieżące analizy na temat skuteczności oddziaływania stylów przywiązania na doświadczanie miłości mogą okazać się użyteczne i pomocne w zrozumieniu i w trakcie rozwiązywania wielu problemów występujących w związkach partnerskich. 
Styl bezpieczny przywiązania stanowi fundamentalny czynnik odpowiadający za to, w jaki sposób kształtuje się doświadczanie miłości. Wyjaśnienia tej relacji można poszukiwać w danych na temat charakterystyki osób przejawiających bezpieczny wzorzec przywiązania. Bezpieczne przywiązanie umożliwia ukształtowanie podstawowego poczucia bezpieczeństwa, które chroni przed konsekwencjami doświadczeń traumatycznych. Osoby o takim stylu doświadczają więcej emocji pozytywnych (Consedine, Magai 2003). Są też zdolne do tworzenia trwałych, stabilnych i nasyconych pozytywnymi emocjami związków (Feeney i in. 2000; Wojciszke 2004). Literatura wskazuje, iż większość związków partnerskich określanych jako satysfakcjonujące jest tworzona na bazie bezpiecznego wzorca przywiązania (McCarthy, Maughan 2010). Istnieją nawet szacunki, iż jest bardziej prawdopodobne, że jeśli osoby charakteryzuje bezpieczny styl przywiązania, to zawrą one związek małżeński (Klohnen, Bera 1998). To, że styl bezpieczny przywiązania stanowi kluczowy fundament pozytywnego doświadczania miłości, wynika z roli tego stylu w rozwoju kompetencji emocjonalnych człowieka (Blatt 1995).

Z kolei pozabezpieczne wzorce przywiązania sprzyjają obniżeniu zadowolenia i satysfakcji ze związku, pojawianiu się negatywnych emocji i lęku, co dezorganizuje doświadczanie miłości (Carver, Scheier 2000). Osoby z pozabezpiecznymi wzorcami przywiązania konstruują relacje silnie powiązane $\mathrm{z}$ trudnościami w utrzymaniu prawidłowych wzorców zachowania (Ward, Lee, Polan 2006). Pozabezpieczny model więzi i ukształtowane w jego efekcie niewłaściwe sposoby radzenia sobie z wczesnymi niekorzystnymi doświadczeniami mogą przyczyniać się do problemów w tworzeniu i utrzymywaniu bliskich związków w dorosłym życiu (McCarthy, Maughan 2010). Na przykład wystąpienie destrukcyjnych zniekształceń powstałych $\mathrm{w}$ dzieciństwie $\mathrm{w}$ rodzinie alkoholowej powoduje wiele nieprawidłowości w zakresie intrapersonalnym i interpersonalnym (Kelley $\mathrm{i}$ in. 2005). Osoby o unikającym stylu przywiązania przejawiają ograniczoną ekspresję emocji i problemy z intymnością w związku (Crawford i in. 2007).

Podłoże wyżej omówionych relacji przywiązanie - doświadczanie miłości może być interpretowane w świetle rozwojowo-funkcjonalistycznego podejścia zaproponowanego przez N.S. Consedine i C. Magai (2003). Wskazuje ono na powiązanie między ekspresją i regulacją emocji a stylami przywiązania. Autorzy tego ujęcia twierdzą, że wewnętrzne modele przywiązania zawierają wiedzę i odpowiednie strategie dotyczące tego, jak regulować emocje i jak wyrażać emocjonalne zaniepokojenie. Osoby przywiązane bezpiecznie posiadają otwarty styl regulacji emocji. Te zaś, u których dominuje unikający styl przywiązania, stosują strategie w kierunku minimalizacji, natomiast osoby posiadające lękowe przywiązanie wykorzystują strategie maksymalizacji regulacji emocji, które mogą być jednocześnie strategiami kompensacyjnymi (Consedine, Magai 2003). Takie powiązania między przywiązaniem i strategiami regulacji emocji zostały potwierdzone także w badaniach podłużnych (Pascuzzo, Cyr, Moss 2013). Podkreśla się zatem, w myśl tego 
ujęcia, funkcjonalne przetwarzanie i regulowanie informacji emocjonalnych u osób przywiązanych bezpiecznie, a dysfunkcyjne przetwarzanie informacji u osób z pozabezpiecznymi stylami przywiązania (Meyer, Pilkonis, Beevers 2004).

Uzyskane rezultaty wpisują się w tezy teorii przywiązania mówiącej o tym, iż wczesnodziecięce doświadczenia są przenoszone w kolejne fazy rozwojowe (Bakermans-Kranenburg, van IJzendoorn 2009). Jednakże na uzyskane wyniki w niniejszych badaniach mogły mieć wpływ pewne ograniczenia związane z zastosowanymi technikami badawczymi. O ile diagnoza doświadczania miłości wydaje się dość trafna, o tyle diagnoza stylów przywiązania może budzić zastrzeżenia. U podłoża zasad obliczania wyników leży założenie, iż jedna osoba może się charakteryzować tylko jednym stylem z trzech diagnozowanych. To wydaje się dość dyskusyjne, ponieważ jest mało prawdopodobne, aby u jednej osoby występował tylko jeden styl przywiązania. Raczej należałoby oczekiwać, iż u osoby występuje zróżnicowane nasilenie różnych stylów przywiązania. Ogólnie ujmując, zastosowana procedura była właściwa w zakresie podjętego problemu badawczego. Być może w celu pełnej weryfikacji związku pomiędzy stylami przywiązania i doświadczaniem miłości należałoby wziąć pod uwagę inne techniki pomiaru przywiązania. W przyszłych badaniach należałoby także uwzględnić charakter oraz dynamikę relacji miłosnej, w jakiej znajduje się osoba badana. Ponadto trzeba właściwie pokategoryzować uczestników badania pod względem cech socjodemograficznych, formy związku czy posiadania dzieci. Dodatkowo niezwykle istotną procedurą empiryczną umożliwiającą dostarczenie ważnych informacji w przedmiotowym zakresie są badania podłużne.

\section{BIBLIOGRAFIA}

Ainsworth, M.D.S., Blehar, M.C., Waters, E., Wall, S. (1978). Patterns of Attachment: A Psychological Study of the Strange Situation. Hillsdale: Erlbaum.

Bakermans-Kranenburg, M.J., van IJzendoorn, M.H. (2009). The first 10000 Adult Attachment Interviews: Distributions of adult attachment representations in clinical and non-clinical groups. Attachment \& Human Development, 11(3), 223-263.

DOI: https://doi.org/10.1080/14616730902814762.

Bartholomew, K., Horowitz, L.M. (1991). Attachment styles among young adults: A test of a four-category model. Journal of Personality and Social Psychology, 61(2), 226-244.

DOI: https://doi.org/10.1037/0022-3514.61.2.226.

Berlin, L.J., Cassidy, J. (1999). Relations among relationships: Contributions from attachment theory and research. W: J. Cassidy, P.R. Shaver (eds.). Handbook of Attachment. Theory, Research and Clinical Applications (s. 688-712). New York-London: The Guilford Press.

Blatt, S.J. (1995). Representational structures in psychopathology. W: D. Cicchetti, S.T. Toth (eds.), Representation, Emotion and Cognition in Developmental Psychopathology (s. 1-33). Rochester: University of Rochester Press. 
Bowlby, J. (2005/1988). A Secure Base. Clinical Applications of Attachment Theory. London-New York: Routlendge Classics.

Bowlby, J. (2007/1969). Przywiazanie. Warszawa: PWN.

Carver, C., Scheier, M. (2000). Perspectives on Personality. Bacon, Boston: Allyn.

Cassidy, J. (1994). Emotion regulation: Influences of attachment relationships. Monographs of the Society for Research in Child Development, 59(2-3), 228-249.

DOI: https://doi.org/10.2307/1166148.

Consedine, N.S., Magai, C. (2003). Attachment and emotion experience in later life: The view from emotions theory. Attachment \& Human Development, 5(2), 165-187.

DOI: https://doi.org/10.1080/1461673031000108496.

Crawford, T.N., Livesley, W.J., Jang, K.L., Shaver, P.R., Cohen, P., Ganiban, J. (2007). Insecure attachment and personality disorders: A twin study of adults. European Journal of Personality, 21(2), 191-208. DOI: https://doi.org/10.1002/per.602.

Crittenden, P. (1994). Peering into the black box: An exploratory treatise on the development of self in young children. W: D. Cicchetti, S.T. Toth, S. (eds.), Disorder and Disfunctions of the Self (Vol. 5; s. 79-148). Rochester: University of Rochester Press.

de Rick, A., Vanheule, S. (2007). Attachment styles in alcoholic inpatients. European Addiction Research, 13, 101-108. DOI: https://doi.org/10.1159/000097940.

Feeney, J.A., Noller, P. (1990). Attachment style as a predictor of adult romantic relationships. Journal of Personality and Social Psychology, 58(2), 281-291.

DOI: https://doi.org/10.1037/0022-3514.58.2.281.

Feeney, L., Noller, P., Roberts, N. (2000). Attachment and Close Relationships. Bulletin of the Menninger Clinic, 62, 147-169.

Finzi, R., Cohen, O., Sapir, Y., Weizman, A. (2000). Attachment styles in maltreated children: A comparative study. Child Psychiatry and Human Development, 31(2), 113-128.

DOI: https://doi.org/10.1023/A:1001944509409.

Fonagy, P. (1998). An attachment theory approach to treatment of the difficult patient. Bulletin of the Menninger Clinic, 62(2), 147-169.

Gawda, B. (2008). Love scripts of person with antisocial personality. Psychological Reports, 103(2), 371-380. DOI: https://doi.org/10.2466/pro.103.2.371-380.

Gawda, B. (2011). Skrypty miłości, nienawiści i lęku u osób antyspołecznych. Warszawa: Difin.

Goldberg, S. (2000). Attachment and Development: The Relationship between Marital Processes and Marital Outcomes. Hillsdale-New York: Lawrence Erlbaum Associates.

Guttmann-Steinmetz, S., Crowell, J.A. (2006). Attachment and externalizing disorders: A developmental psychopathology perspective. Journal of the American Academy of Child and Adolescent Psychiatry, 45(4), 440-451. DOI: https://doi.org/10.1097/01.chi.0000196422.42599.63.

Harnic, D., Digiacomantonio, V., di Marzo, S., Sacripanti, F., Saioni, R., Mazza, M., ..., Janiri, L. (2010). P03-213 - Temperament and attachment in patients with alcohol dependence. European Psychiatry (Suppl.), 1(25), 1280-1280. DOI: https://doi.org/10.1016/S0924-9338(10)71267-0.

Hazan, C., Shaver,P.(1987). Romantic love conceptualized as an attachment process. Journal of Personality and Social Psychology, 52(3), 511-524. DOI: https://doi.org/10.1037/0022-3514.52.3.511. 
Hazan, C., Shaver, P. (1994). Attachment as an Organizational Framework for Research on Close Relationships. Psychological Inquiry, 5(1), 1-22.

DOI: https://doi.org/10.1207/s15327965pli0501_1.

Hesse, E. (1999). The adult attachment interview: Historical and current perspectives. W: J. Cassidy, P.R. Shaver (eds.). Handbook of Attachment. Theory, Research, and Clinical Applications (s. 395-433). New York-London: The Guilford Press.

Juen, F., Arnold, L., Meissner, D., Nolte, T., Buchheim, A. (2013). Attachment disorganization in different clinical groups: What underpins unresolved attachment? Psihologija, 46(2), 127141. DOI: https://doi.org/10.2298/PSI1302127J.

Kelley, M.L., Nair, V., Rawlings, T., Cash, T.F., Steer, K., Fals-Stewart, W. (2005). Retrospective reports of parenting received in their families of origin: Relationships to adult attachment in adult children of alcoholics. Addictive Behaviors, 30(8), 1479-1495.

DOI: https://doi.org/10.1016/j.addbeh.2005.03.005.

Klohnen, E.C., Bera, S. (1998). Behavioral and experiential patterns of avoidantly and securely attached women across adulthood: A 31-year longitudinal perspective. Journal of Personality \& Social Psychology, 74(1), 211-223. DOI: https://doi.org/10.1037/0022-3514.74.1.211.

McCarthy, G., Maughan, B. (2010). Negative childhood experiences and adult love relationships: The role of internal working models of attachment. Attachment \& Human Development, 12(5), 445-461. DOI: https://doi.org/10.1080/14616734.2010.501968.

Meyer, B., Pilkonis, P.A., Beevers, C.G. (2004). What's in a (neutral) face? Personality disorders, attachment styles, and the appraisal of ambiguous social cues. Journal of Personality Disorders, 18(4), 320-338. DOI: https://doi.org/10.1521/pedi.2004.18.4.320.

Mikulincer, M. (1998). Attachment working models and the sense of trust: An exploration of interaction goals and affect regulation. Journal of Personality and Social Psychology, 74(5), 1209-1224. DOI: https://doi.org/10.1037/0022-3514.74.5.1209.

Pascuzzo, K., Cyr, C., Moss, E. (2013). Longitudinal association between adolescent attachment, adult romantic attachment, and emotion regulation strategies. Attachment \& Human Development, 15(1), 83-103. DOI: https://doi.org/10.1080/14616734.2013.745713.

Pervin, L.A. (2002). Psychologia osobowości. Gdańsk: GWP.

Plopa, M. (2005). Psychologia rodziny. Teoria i badania. Kraków: Oficyna Wydawnicza „Impuls”.

Plopa, M. (2008). Więzi w matzeństwie i rodzinie. Metody badań. Kraków: Oficyna Wydawnicza „Impuls”.

Ragnoni, E., Galati, D., Costa, T., Crini, M. (2008). Relationship between adult attachment patterns, emotional experience and EEG frontal asymmerty. Personality and Individual Differences, 44(4), 909-920. DOI: https://doi.org/10.1016/j.paid.2007.10.021.

Shaver, P.R., Hazan, C., Bradshaw, D. (1988). Love as attachment: The integration of three behavioral systems. W: R.J. Sternberg, M. Barnes (eds.), The Psychology of Love (s. 68-99). New Haven: Yale University Press.

Sroufe, L.A., Carlson, E.A., Levy, A.K., Egeland, B. (1999). Implications of attachment theory for developmental psychopathology. Development and Psychopathology, 11(1), 1-13.

DOI: https://doi.org/10.1017/S0954579499001923. 
Sternberg, R.J., Weis, K. (red.). (2007). Nowa psychologia miłości. Taszów: Moderator.

Thompson, R.A., Goodvin, R. (2007). Taming the tempest in the teapot: Emotion regulation in toddlers. W: C.A. Brownell, C.B. Kopp (eds.), Socioemotional Development in the Toddler Years (s. 320-341). New York: Guilford Press.

Thorberg, F.A., Lyvers, M. (2006). Attachment, fear of intimacy and differentiation of self among clients in substance disorder treatment facilities. Addictive Behaviors, 31(4), 732-737.

DOI: https://doi.org/10.1016/j.addbeh.2005.05.050.

Wallin, D.J. (2011). Przywiąanie w psychoterapii. Kraków: Wydawnictwo UJ.

Ward, M.J., Lee, S.S., Polan, H.J. (2006). Attachment and psychopathology in a community sample. Attachment \& Human Development, 8(4), 327-340.

DOI: https://doi.org/10.1080/14616730601048241.

Waters, E., Merrick, S., Treboux, D., Crowell, J., Albersheim, L. (2000). Attachment security in infancy and early adulthood: A twenty-year longitudinal study. Child Development, 71(3), 684-689. DOI: https://doi.org/10.1111/1467-8624.00176.

Wedekind, D., Bandelow, B., Heitmann, S., Havemann-Reinecke, U., Engel, K.R., Huether, G. (2013). Attachment style, anxiety coping, and personality-styles in withdrawn alcohol addicted inpatients. Substance Abuse Treatment, Prevention, and Policy, 8(1).

DOI: https://doi.org/10.1186/1747-597X-8-1.

Wojciszke, B. (2004). Człowiek wśród ludzi. Zarys psychologii społecznej. Warszawa: Wydawnictwo Naukowe Scholar.

Zeifman, D., Hazan, C. (2000). A Process Model of Adult Attachment Formation. W: W. Ickes, S. Duck (eds.), The Social Psychology of Personal Relationship (s. 37-54). Chichester: J. Wiley \& Sons.

\section{SUMMARY}

The literature on the subject suggests that attachment is a key mechanism in human development. The model of attachment develops in early childhood and influences the way of establishing close relationships in subsequent phases of life as well as the development of various mental disorders (Berlin, Cassidy 1999; Bowlby 2007/1969). The aim of the paper is to determine the relations between attachment styles and the experience of love in groups of prisoners and non-prisoners. Two studies were conducted: a study of prison inmates $(\mathrm{n}=314)$ and a study of subjects from the general population ( $\mathrm{n}=259)$. Attachment style was examined by means of the Attachment Styles Questionnaire by M. Plopa (2008), and the experience of love was analyzed based on the narrative analysis technique. We computed multiple regression to show how particular dimensions of attachment best determine the ways of experiencing love. The main attachment style explaining the experience of love turned out to be a secure style.

Keywords: attachment styles; experience of love; prison inmates 